\title{
Relationship between Heavy Metal Concentrations in Bottom Sediments and the Clam, Galatea Paradoxa (Born 1778) from the Volta Estuary, Ghana
}

\author{
Hashem A. Madkour ${ }^{1}$, Kwasi A. Obirikorang ${ }^{2}$, Steve Amisah ${ }^{2}$, Fred A. Otchere ${ }^{3}$, \\ Daniel Adjei-Boateng ${ }^{2}$
}

\footnotetext{
${ }^{1}$ National Institute of Oceanography and Fisheries (NIOF), Red Sea Branch, Hurghada, Egypt; ${ }^{2}$ Department of Fisheries and Watershed Management, Faculty of Renewable Natural Resources, Kwame Nkrumah University of Science and Technology (KNUST), Kumasi, Ghana; ${ }^{3}$ Binpal Engineering Ltd., Surrey, Canada.

Email:madkour_hashem@yahoo.com,quasiadu@yahoo.com, steveamisah1@yahoo.co.uk, atotchere@yahoo.co.uk, adjeiboat@yahoo.com
}

Received January $3^{\text {rd }}, 2011$; revised May $2^{\text {nd }}, 2011$; accepted June $7^{\text {th }}, 2011$.

\begin{abstract}
This research was carried out at two locations, Ada and Aveglo at the Volta Estuary, Ghana to evaluate the importance of sediments as regulatory media in controlling the levels of four metals, Manganese (Mn), Zinc (Zn), Iron (Fe) and Mercury $(\mathrm{Hg})$ in the tissues of the clam, Galatea paradoxa (Born 1778) and to investigate the possible relationships between the concentrations of the metals in the sediments and the clams. The clams were categorized into three size classes as follows: small (25-40 mm), medium (41 - $55 \mathrm{~mm})$, and large (above $55 \mathrm{~mm})$. To understand the possible relationships between the concentrations of the studied metals in the sediments and in the tissues of the three clam size classes, the monthly concentrations of the studied metals were graphed and subjected to Pearson correlation analyses $(p<0.05)$ to identify metal accumulation patterns and determine whether or not positive relationship patterns existed between the concentrations in the clams and sediment samples. The correlation revealed no simple linear relationships between the concentrations of four heavy metals in the clam tissues and the sediments at the two sampling stations although some distinct trends were observed. Mn concentrations in the clams and sediments from the two stations showed some clear positive relationship patterns with some increments in monthly sediment concentrations resulting in increments in clam tissue concentrations. This relationship though, was not too clear-cut.
\end{abstract}

Keywords: Heavy Metal, Galatea Paradoxa, Sediments, Volta Estuary

\section{Introduction}

Sediments are an important sink for a variety of pollutants, particularly heavy metals and may serve as an enriched source of such pollutants, especially in estuarine ecosystems. In some cases, sediments may hold over $99 \%$ of the total amount of heavy metals present in an ecosystem [1] and these metals may be present in the estuarine system as dissolved species, as free ions or forming organic complexes with humic and fulvic acids. Additionally, many metals associate readily with particulates and become adsorbed or co-precipitated with carbonates, oxyhydroxides, sulphides and clay minerals. Consequently, sediments accumulate contaminants and may act as long-term stores for metals in the environment [2]. Exposure of sediment-dwelling organisms to metals may occur via uptake of interstitial waters, ingestion of sediment particles and via the food chain [3]. The occurrence of elevated concentrations of trace metals in sediments found at the bottom of the water column can be a good indicator of man-induced pollution rather than natural enrichment of the sediment by geological weathering $[4,5]$.

Bivalves as sedentary filter feeders usually have the ability to accumulate high metal concentrations in their tissues without metabolising them appreciably [6-8]. Bottom sediments are an important source of heavy metals to bivalves because heavy metals tend to adhere to 
sediment particles and if bivalves take in these sediment particles as part of their normal feeding process, the heavy metals are also ingested [9]. This research was thus carried out at the Volta Estuary, Ghana to evaluate the importance of sediments as regulatory media in controlling the levels of four metals, Manganese (Mn), Zinc $(\mathrm{Zn})$, Iron $(\mathrm{Fe})$ and Mercury $(\mathrm{Hg})$ in the tissues of the clam, Galatea paradoxa (Born 1778) and to investigate the possible relationships between the concentrations of the metals in the sediments and the clams.

\section{Methodology}

\subsection{Study Area}

The study was carried out at Ada and Aveglo, both at the Volta Estuary, Ghana, over an 18-month period, from March 2008 to August 2009. Ada (Latitude 05 $49^{\prime} 18.6^{\prime \prime}$ $\mathrm{N}$ and $\left.000^{\circ} 38.46^{\prime} 1^{\prime \prime} \mathrm{E}\right)$ and Aveglo $\left(05^{\circ} 53^{\prime} 28.2^{\prime \prime} \mathrm{N}\right.$ and $\left.000^{\circ} 38^{\prime} 24.7^{\prime \prime} \mathrm{E}\right)$ represent the southern and northern limits of the most active clam fishing grounds at the Volta Estuary (Figure 1).

\subsection{Study Species}

The clam, Galatea paradoxa (Born 1778) is a commercially important bivalve species exploited mainly for its flesh and is consumed boiled or fried. It is a filter-feeding organism with a wide distribution extending from the Gulf of Guinea to the Congo [10]. Limited information about the prevalence and commercial exploitation of this clam is available from only a few countries, including Ghana, Nigeria and Cameroon, despite its extensive distribution in the wider West African region [11]. In Ghana, the Volta estuary represents the main fishing grounds of G. paradoxa. Clam fishing represents a viable source of income and livelihood for the local people. Furthermore, it constitutes an important and affordable protein source to the riparian communities along the Volta estuary and beyond [12].

\section{Collection and Processing of Samples}

\section{Surface Sediments}

Riverbed sediment samples were collected on a monthly interval for 18 months using an Ekman grab at the two locations from March 2008 to August 2009. Sediment samples were collected from each sampling sites according to the standard procedures described in USEPA's sediment sampling guide [13] and were kept in LDPE bottles pre-washed with $10 \% \mathrm{HC} 1$ and stored in insulated iced chests for analysis in the laboratory. In the laboratory, $500 \mathrm{~g}$ of the sediment subsamples from each

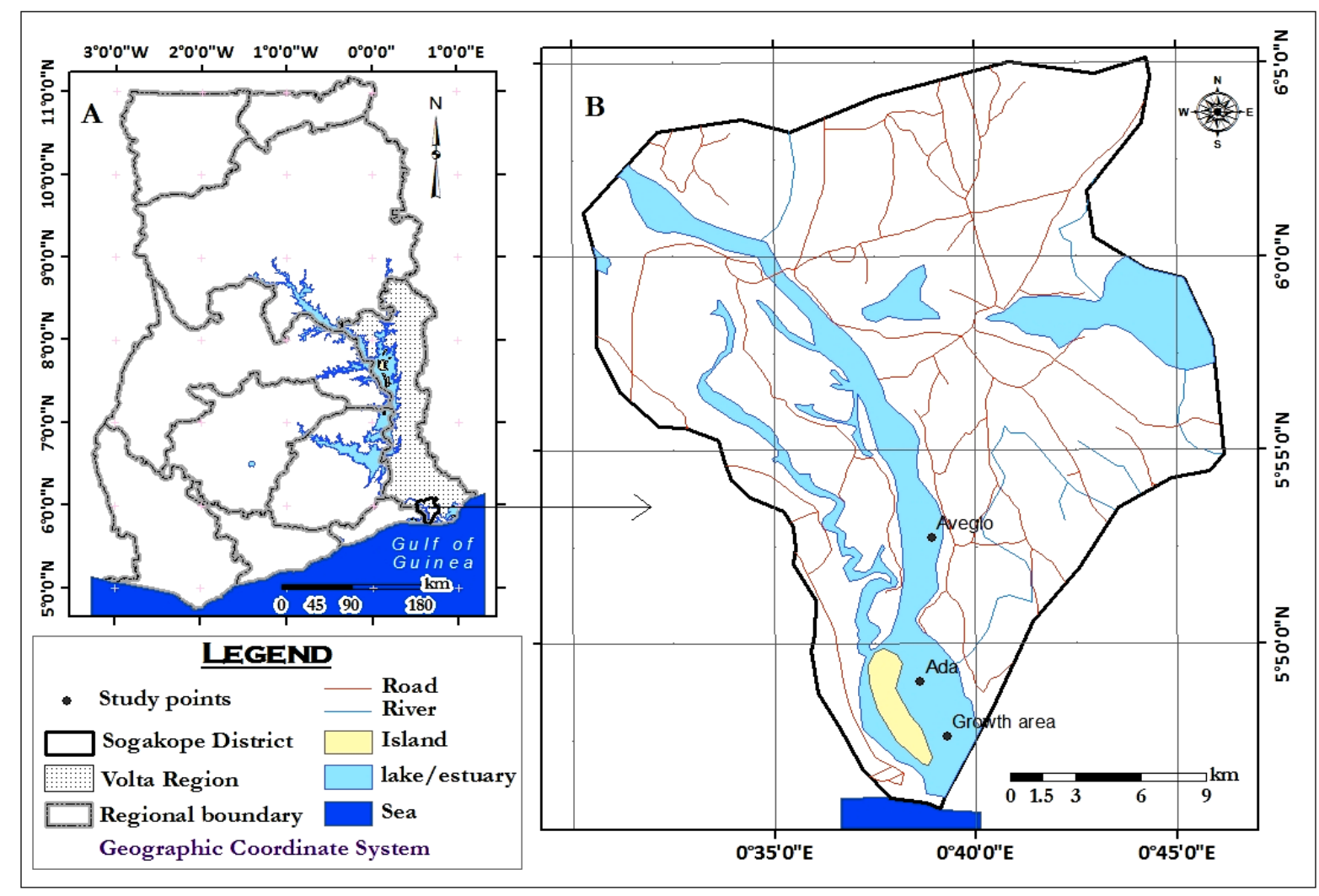

Figure 1. Map showing the clam sampling locations at Ada and Aveglo in the Volta estuary in Ghana. 
sampling location were placed in ceramic mortars for drying at $80^{\circ} \mathrm{C}$ for $48 \mathrm{hrs}$ to a constant weight [14]. The dried samples were then gently disaggregated and $250 \mathrm{~g}$ of each sample stored in $250 \mathrm{ml}$ acid-washed LDPE bottles and kept at $4{ }^{\circ} \mathrm{C}$ in a refrigerator for heavy metal and analyses [13].

\section{Clam Samples}

Clam samples were obtained from fishermen's catch from the two sampling stations at monthly intervals for 18 months and transported to the laboratory, submerged in river water, in insulated chests within 12 hours for processing and storage for heavy metal analyses. In the laboratory, clam samples were cleansed to remove the mud and any debris and then washed with double distilled water. For each site, clams of various sizes were obtained and grouped into three size classes of 10 individuals, each based on shell lengths. The categorization was as follows: small $(25-40 \mathrm{~mm})$, medium (41 - 55 $\mathrm{mm}$ ), and large (above $55 \mathrm{~mm}$ ). The various clam size classes were purged of ingested organic and inorganic particles before being analyzed for heavy metal accumulation by keeping each size class in distilled water for a 24-hour depuration. After the depuration process, a sterile stainless steel knife was used to dislodge and remove the soft tissue of each clam from the shell [15]. The flesh of each subsample was oven-dried to a constant weight at $60^{\circ} \mathrm{C}$ for 48 hours. Each dry clam sample was weighed on a Sartorius BP $210 \mathrm{~S}$ micro balance to the nearest $0.0001 \mathrm{~g}$. Individuals of each size class were ground together into fine powder using a porcelain pestle and mortar. Homogenized subsamples were stored in airtight, acid-washed $(0.1 \mathrm{MHCl})$ snap-top glass vials for heavymetal analyses [16].

\section{Digestion of the Samples}

About $0.5 \mathrm{~g}$ of the homogenized clam subsamples and sediment samples were weighed into a $50 \mathrm{ml}$ digestion tube and $1 \mathrm{ml}$ of distilled water, $2.0 \mathrm{ml}$ perchloric acid (HNO3-HClO4) (1:1 vv) and $5.0 \mathrm{ml}$ sulphuric acid (H2SO4) were added. Each mixture was refluxed at $200^{\circ} \mathrm{C}$ for 30 minutes in a clean fume chamber. The completely digested subsamples were allowed to cool at room temperature, and the undigested portions were filtered off through a Whatmann Glass Microfibre filter paper $(\mathrm{GF} / \mathrm{C})$ to obtain a clear solution and diluted to 50 $\mathrm{ml}$ in volumetric flasks with double distilled water [17, $18]$.

\section{Determination of $\mathrm{Zn}, \mathrm{Fe}$ and $\mathrm{Mn}$}

Concentrations of $\mathrm{Mn}, \mathrm{Zn}$ and $\mathrm{Fe}$ were determined using a Buck Scientific Model VGP flame Atomic Absorption Spectrophotometer (AAS) and the wavelengths and detection limits for the studied metals are shown in Table 1. All tissue and sediment analytical batches were
Table 1. Wavelengths and detection limits for the studied heavy metals.

\begin{tabular}{llll}
\hline Element & Slit & Wavelength & Detection Limit \\
\hline Manganese & 0.7 & 385.2 & 0.001 \\
Zinc & 0.7 & 213.9 & 0.005 \\
Iron & 0.7 & 248.3 & 0.03 \\
\hline
\end{tabular}

accompanied by blanks at a minimum rate of one blank per 20 samples. Replicate analyses were conducted on $10 \%$ of the samples to evaluate precision of the analytical techniques. The data were expressed as total concentration $(\mu \mathrm{g} / \mathrm{g}$ dry weight $(\mathrm{dw})$.

Determination of Total Mercury (THg)

The Automatic Mercury Analyzer (Model HG 5000) equipped with a mercury lamp at a wavelength $253.7 \mathrm{~nm}$ was used for the determination of Total Mercury (THg) in the clam soft tissue and sediment samples. Responses were recorded on strip chart recorders as sharp peaks. The peak heights were used for computation of the total mercury concentrations in the clam and expressed as microgram per gram dry weight $(\mu \mathrm{g} / \mathrm{g} \mathrm{dw})$. Total mercury concentrations were validated according to standard procedures described for Mercury Analyzer Model HG 5000 to check for precision and accuracy.

Physicochemical Water Parameters

Monthly measurement of temperature, salinity, $\mathrm{pH}$, pressure, total dissolved solids (TDS), conductivity and dissolved oxygen (DO) of the Volta River were taken at both sites for the period using a Hanna (HI 9028) multi-parameter probe.

Statistical Analysis

The evaluation of the relationship between the concentrations of the four heavy metals in the tissues of the three clam sizes and the sediment samples was performed using the Pearson correlation $(\mathrm{p}<0.05)$. All descriptive statistics and graphs were executed using the GraphPad Prism 5 Software.

\section{Results}

\subsection{Physicochemical Parameters of the Volta Estuary}

The physicochemical parameters of the Estuary over the 18-month sampling period were fairly similar at the two sampling locations. The summary of the results are shown in Table 2.

\subsection{Metal Concentrations in the Tissues of the Clams}

Ada Sampling Station

Manganese (Mn) concentration in the whole soft tissue of the small-sized clams varied from $73 \mu \mathrm{g} / \mathrm{g}$ in June 2008 to $867 \mu \mathrm{g} / \mathrm{g}$ in July that same year depicting a rela 
Table 2. Physicochemical parameters of the volta estuary at ada and aveglo.

\begin{tabular}{llll}
\hline $\begin{array}{l}\text { Sampling } \\
\text { Station }\end{array}$ & Parameter & Range & Mean \pm SD \\
\hline Ada & $\mathrm{pH}$ & $6.18-8.50$ & $6.94 \pm 0.52$ \\
& Temperature $\left({ }^{\circ} \mathrm{C}\right)$ & $27.28-29.59$ & $28.60 \pm 0.80$ \\
& Salinity & $0.02-0.03$ & $0.027 \pm 0.005$ \\
& DO $(\mathrm{mg} / \mathrm{l})$ & $1.52-8.76$ & $4.19 \pm 1.93$ \\
& TDS $(\mathrm{mg} / \mathrm{l})$ & $27-35$ & $30.06 \pm 2.65$ \\
& Conductivity $(\mu \mathrm{S} / \mathrm{cm})$ & $52-70$ & $60 \pm 5.16$ \\
Aveglo & pH & $6.23-7.28$ & $6.85 \pm 0.27$ \\
& Temperature $\left({ }^{\circ} \mathrm{C}\right)$ & $27.19-29.62$ & $28.68 \pm 0.69$ \\
& Salinity & $0.02-0.04$ & $0.028 \pm 0.005$ \\
& DO $(\mathrm{mg} / \mathrm{l})$ & $1.58-6.79$ & $3.89 \pm 1.80$ \\
& TDS $(\mathrm{mg} / \mathrm{l})$ & $27-42$ & $31 \pm 3.48$ \\
& Conductivity $(\mu \mathrm{S} / \mathrm{cm})$ & $54-84$ & $62.83 \pm 7.62$ \\
\hline
\end{tabular}

tively wider variation in Mn concentrations. The mediumsized clams recorded $\mathrm{Mn}$ values of between $68 \mu \mathrm{g} / \mathrm{g}$ in May 2008 and $336 \mu \mathrm{g} / \mathrm{g}$ in August 2008. Mn concentration in the tissues of the large-sized clams ranged from $49 \mu \mathrm{g} / \mathrm{g}$ in June 2008 to $316 \mu \mathrm{g} / \mathrm{g}$ in February, 2009. The highest concentration of $\mathrm{Zn}$ in the tissue of the smallsized clams $(59 \mu \mathrm{g} / \mathrm{g})$ was recorded December 2008 with the lowest concentrations of $19 \mu \mathrm{g} / \mathrm{g}$ being recorded in the month of August of the same year. Concentrations of $13 \mu \mathrm{g} / \mathrm{g}$ and $57 \mu \mathrm{g} / \mathrm{g}$ were recorded as the lowest and highest concentrations for the medium-sized clams in the months of March and December, 2008 respectively. In the large-sized clams, $\mathrm{Zn}$ concentrations varied between $16 \mu \mathrm{g} / \mathrm{g}$ in March 2008 and $49 \mu \mathrm{g} / \mathrm{g}$ in December, 2008. The results obtained for $\mathrm{Fe}$ in the tissues of the small-sized clams indicated a highest value of $484 \mu \mathrm{g} / \mathrm{g}$ in January 2009 and a lowest value of $103 \mu \mathrm{g} / \mathrm{g}$ in November, 2008. The medium-sized clams recorded $\mathrm{Fe}$ concentrations ranging from $79 \mu \mathrm{g} / \mathrm{g}$ to $340 \mu \mathrm{g} / \mathrm{g}$ in April 2009 and February 2009 respectively. The large- sized clams recorded values ranging from a low of $96 \mu \mathrm{g} / \mathrm{g}$ in June 2009 to a high of $313 \mu \mathrm{g} / \mathrm{g}$ in January 2009. Total Mercury (THg) concentrations for the small-sized clams ranged from $0.028 \mu \mathrm{g} / \mathrm{g}$ in April 2008 to $0.042 \mu \mathrm{g} / \mathrm{g}$ in August 2008. The medium-sized clams recorded a highest $\mathrm{THg}$ value of $0.049 \mu \mathrm{g} / \mathrm{g}$ in March and September 2008 and a lowest value of $0.035 \mu \mathrm{g} / \mathrm{g}$ in April 2008 . $\mathrm{THg}$ concentrations ranged between a low of $0.044 \mu \mathrm{g} / \mathrm{g}$ and high of $0.059 \mu \mathrm{g} / \mathrm{g}$ in July 2008 and September 2008 in the large-sized clams.

\section{Aveglo Sampling Station}

The highest concentration of $\mathrm{Mn}$ in the small-sized clams was observed in February 2009 (201 $\mu \mathrm{g} / \mathrm{g})$ and lowest in June $2008(79 \mu \mathrm{g} / \mathrm{g})$. The medium-sized clams recorded concentrations varying between a low of 73 $\mu \mathrm{g} / \mathrm{g}$ in May and June 2008 and $206 \mu \mathrm{g} / \mathrm{g}$ in March of the same year. The large-sized clams recorded values rang- ing from $72 \mu \mathrm{g} / \mathrm{g}$ in November 2008 to $228 \mu \mathrm{g} / \mathrm{g}$ in $\mathrm{Au}-$ gust 2008. $\mathrm{Zn}$ concentrations for the small-sized clams ranged from a lowest value of $25 \mu \mathrm{g} / \mathrm{g}$ in April 2008 to a highest value of $59 \mu \mathrm{g} / \mathrm{g}$ in December of the same year. Values of $16 \mu \mathrm{g} / \mathrm{g}$ and $54 \mu \mathrm{g} / \mathrm{g}$ in June and December 2008 respectively were recorded as the lowest and highest values for the medium-sized clams. The large-sized clams recorded $\mathrm{Zn}$ concentrations ranging from $16 \mu \mathrm{g} / \mathrm{g}$ in June 2008 and $48 \mu \mathrm{g} / \mathrm{g}$ in September and December 2008. Results from the monthly analyses of $\mathrm{Fe}$ in the tissues of the small-sized clams indicated a lowest value of $119 \mu \mathrm{g} / \mathrm{g}$ in October 2008 and a highest value of 427 $\mu \mathrm{g} / \mathrm{g}$ in January 2009. The medium-sized clams had Fe concentrations ranging between a low of $72 \mu \mathrm{g} / \mathrm{g}$ and a high of $539 \mu \mathrm{g} / \mathrm{g}$ in November 2008 and March 2008 respectively. $79 \mu \mathrm{g} / \mathrm{g}$ and $304 \mu \mathrm{g} / \mathrm{g}$ were the lowest and highest values recorded in the months of November 2008 and January 2009 respectively for the large-sized clams. $\mathrm{THg}$ concentrations in the tissues of the small-sized clams ranged from $0.037 \mu \mathrm{g} / \mathrm{g}$ to $0.055 \mu \mathrm{g} / \mathrm{g}$ in May and March 2008 respectively. Sampled medium-sized clams recorded values ranging from $0.042 \mu \mathrm{g} / \mathrm{g}$ in July 2008 to $0.056 \mu \mathrm{g} / \mathrm{g}$ in August 2008. The large-sized clams had a lowest $\mathrm{THg}$ concentration of $0.037 \mu \mathrm{g} / \mathrm{g}$ in March 2008 and a highest concentration of $0.074 \mu \mathrm{g} / \mathrm{g}$ in June 2008 .

\subsection{Metal Concentrations in the Sediment Samples}

\section{Ada Sampling Station}

The concentrations of $\mathrm{Mn}$ in the sediments sampled from the Ada sampling station did not vary considerably over the 18-month period and were generally similar. The lowest Mn concentration of $110 \mu \mathrm{g} / \mathrm{g}$ was recorded in November 2008 whiles the highest of $393 \mu \mathrm{g} / \mathrm{g}$ was recorded in March 2009. Zn concentrations were generally very low in the Ada sediments with very small variations in concentrations over the sampling period. Concentrations were observed to be lowest in September 2008 where concentrations were in trace amounts below the detection limit of the AAS. A concentration of $9 \mu \mathrm{g} / \mathrm{g}$ was recorded in the month of July 2009 as the highest $\mathrm{Zn}$ concentrations during the sampling period. The monthly Fe concentrations over the sampling period were generally very high and followed no particular pattern. Concentrations varied from a lowest value of $696 \mu \mathrm{g} / \mathrm{g}$ in August 2008 to $2758 \mu \mathrm{g} / \mathrm{g}$ in March of the same year. Concentrations of $\mathrm{THg}$ ranged from $0.0069 \mu \mathrm{g} / \mathrm{g}$ to $0.0240 \mu \mathrm{g} / \mathrm{g}$ in the months of April and August 2008 respectively.

\section{Aveglo Sampling Station}

Mn concentrations in the Aveglo sediments varied from a low of $100 \mu \mathrm{g} / \mathrm{g}$ in May 2008 to $290 \mu \mathrm{g} / \mathrm{g}$ in Au- 
gust 2008. Concentrations of $\mathrm{Zn}$ in the sediments were very low, similar to the concentrations recorded at Ada between the months of May and September of 2008. Zn values ranged from the lowest value $1 \mu \mathrm{g} / \mathrm{g}$ in the months of October and November 2008 to the highest of $8 \mu \mathrm{g} / \mathrm{g}$ in the months of May and June 2009. Fe concentrations were relatively very high with the lowest concentration of $1114 \mu \mathrm{g} / \mathrm{g}$ recorded in June 2008 and the highest value of $3476 \mu \mathrm{g} / \mathrm{g}$ in August of 2008. THg concentrations in the sediments were far lower than the concentrations recorded in the tissues of the clams of all the three size classes. The lowest concentration of $0.0078 \mu \mathrm{g} / \mathrm{g}$ was observed in May 2008 and the highest of $0.0230 \mu \mathrm{g} / \mathrm{g}$ in June 2008.

\subsection{Relationship between Metal Concentrations in Sediments and Clam Tissues}

G. paradoxa are predominantly found at the sedimentwater interface and thus metal contaminants in the sediments have a potential to significantly influence the metal concentrations in their tissues.

To understand the possible relationships between metal concentration in the sediments and accumulation in the tissues of the three clam size classes as far as $\mathrm{Mn}, \mathrm{Zn}$, $\mathrm{Fe}$ and $\mathrm{Hg}$ were concerned, the monthly concentrations of the studied metals were graphed and subjected to Pearson correlation analyses $(p<0.05)$ to identify metal accumulation patterns and determine whether or not positive relationship patterns existed between the concentrations in the clams and sediment samples (Figures 2 and 3).

The correlation analyses revealed no simple linear relationships between the concentrations of four heavy metals in the clam tissues and the sediments at the two sampling stations although some distinct trends were observed. Mn concentrations in the clams and sediments from the two stations showed some clear positive relationship patterns with some increments in monthly sediment concentrations resulting in increments in clam tissue concentrations. This relationship though, was not too clear-cut.

No defined accumulation patterns were established for $\mathrm{Zn}, \mathrm{Fe}$ and $\mathrm{Hg}$ concentrations at the two sampling locations. $\mathrm{Zn}$ concentrations in the sediment samples were consistently low with values over the 18-month sampling period all falling below $10 \mu \mathrm{g} / \mathrm{g}$. Fe concentrations on the other hand were clearly higher in the sediment samples and showed no distinct link with the concentrations in the clam tissues.

Results of the Spearman correlation analyses revealed no positive correlation $(p>0.05)$ between sediment con- centrations of the four metal and the concentrations in the tissues of the three clam size classes.

\section{Discussion}

It is generally agreed that heavy metal uptake occurs mainly from water, food and sediment. However, effectiveness of metal uptake from these sources may differ in relation to ecological needs and metabolism of animals and concentrations of the heavy metals in water, food and sediment as well as some other factors such as salinity, temperature and interacting agents [19].

Analyses of the clam and sediment samples revealed no distinct relationship between heavy metal levels in clam tissues and sediments in which they thrive. An observation of the concentrations of all the clam size classes and sediments from the two stations revealed no significant relationship patterns, indicating no distinct trend in metal uptake by the clams as far as the sediment in/on which they are found is concerned. A possible explanation of this phenomenon could be that heavy metal accumulation in the clams may not be directly or solely derived from sediments. Other sources of heavy metals in bivalve tissues are derived from living or dead suspended particles and from dissolved metals in the water [20].

According to [20], the release of heavy metal from sediments and the subsequent availability to living things is controlled by the behaviour of heavy metals themselves, and the physical and chemical condition of the surrounding environment and this probably explains why there are no clear relationships between the concentration of heavy metals in clam tissues, and those in sediment. For example, although monthly concentrations of $\mathrm{Fe}$ in the sediments from both stations were markedly higher than Mn concentrations, the monthly concentrations of the two metals were relatively similar in the tissues of the clams. This phenomenon could be due to the fact that $\mathrm{Fe}$ is deposited much more quickly but is strongly bound to the sediments under the estuarine conditions [20]. Fe is, thus, not readily available to the clams as far as the sediments are concerned as a heavy metal source. Mn on the other hand can be said to be released much more easily from sediments than $\mathrm{Fe}$ and thus is more readily available to the clams.

The relatively consistent monthly concentrations of $\mathrm{Mn}, \mathrm{Fe}$ and $\mathrm{Zn}$ in whole soft tissues of G. paradoxa may well represent efficient metabolism and detoxifying processes that include transportation, transformation, sequestration and/or excretion of excess metals [21]. The results further suggest that the levels of contamination of these metals do not exceed the clam's capacity of regulation $[22,23]$. The relatively higher concentrations of $\mathrm{Zn}$ 

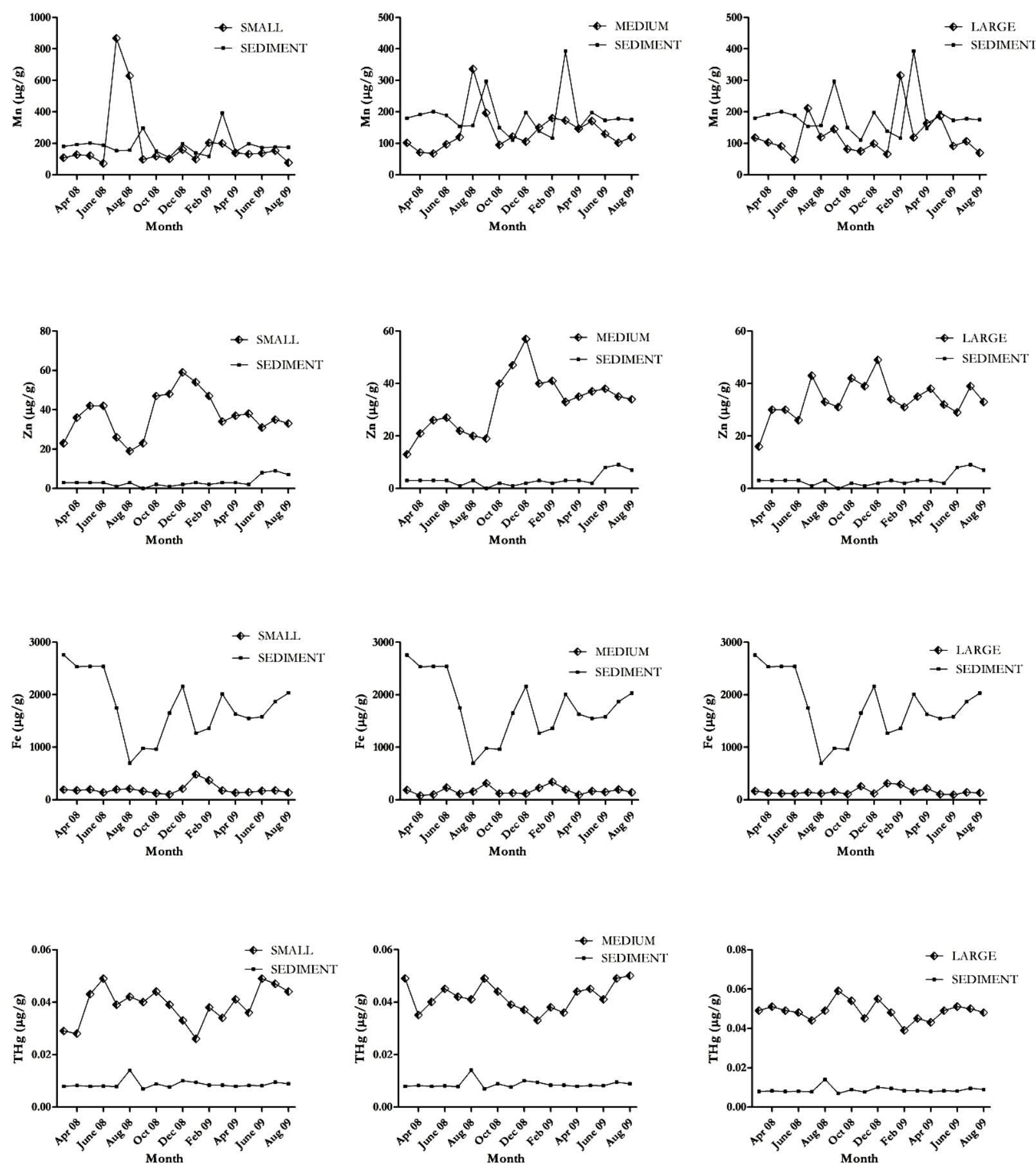

Figure 2. Relationships between Mn, Zn, Fe and Hg concentrations in the tissues of the different clam size classes and sediments from the Ada sampling station.

in the clam tissues compared to the concentrations in the sediments suggests a high rate of accumulation by the clams - a physiological mechanism induced by exposure or even a high relevance of the water as an additional source of contamination [24].

Biological variables such as size, sex or changes in 

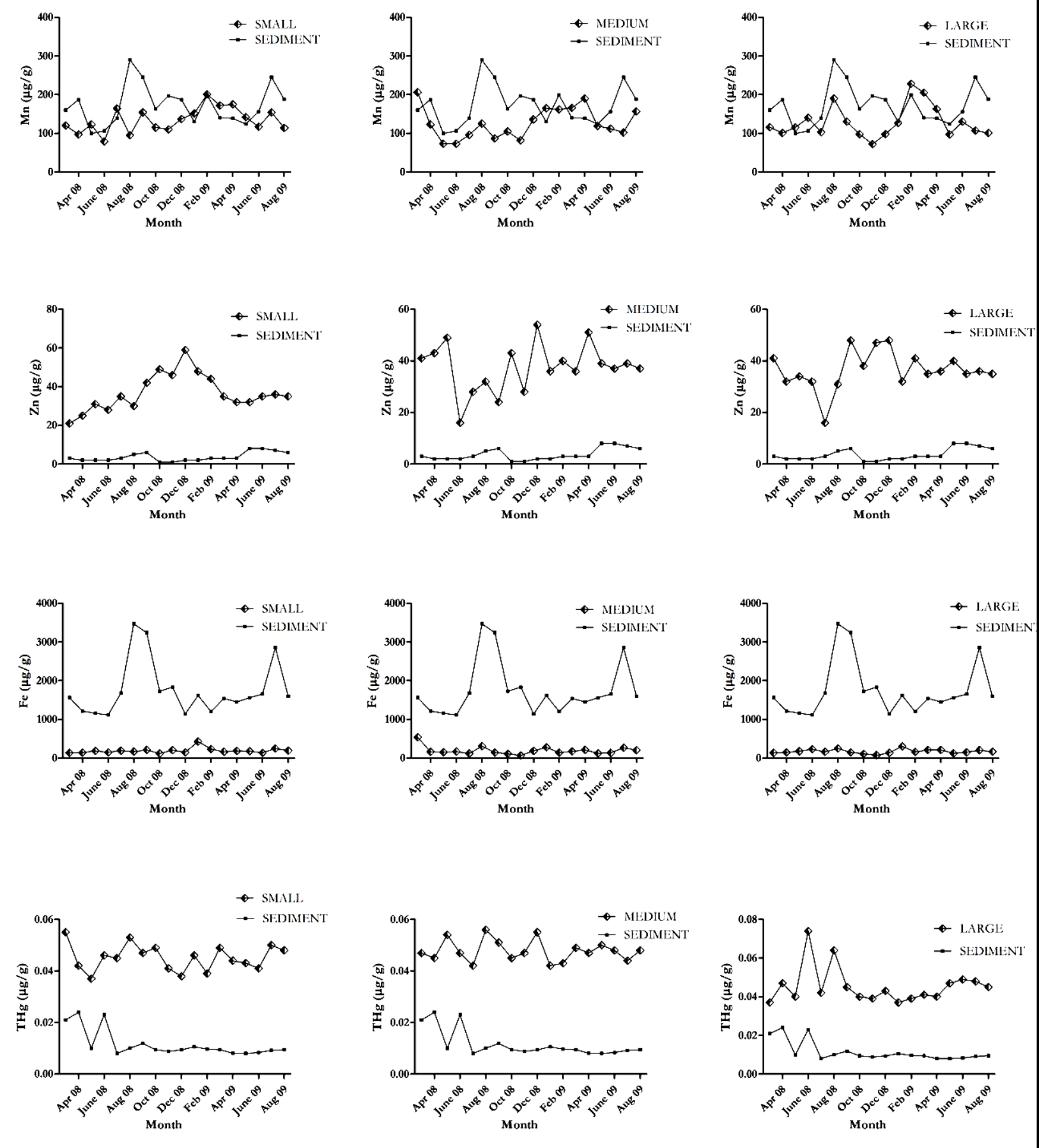

Figure 3. Relationships between $\mathrm{Mn}, \mathrm{Zn}, \mathrm{Fe}$ and $\mathrm{Hg}$ concentrations in the tissues of the different clam size classes and sediments from the Aveglo sampling station.

tissue composition and reproductive cycle as well as the season of sampling and the hydrodynamics of the estuary have to be considered as far as variations in metal concentrations are concerned. Seasonal variations have been reported to be higher in winter/dry than in summer/wet. These seasonal variations have been related to a great extent to seasonal changes in flesh weight during development of gonadic tissues [18,25-27]. Variability of 
heavy metal concentrations can also be caused by changes in the physiological conditions of the clams [28, 29] and environmental parameters including temperature, $\mathrm{pH}$, salinity, oxygen concentrations [30,31]. Except Hg, all the metals examined in this study are essential for clams and have intracellular regulatory mechanisms [32] to keep their concentrations in the clam tissues in equilibrium.

\section{Conclusions}

The study revealed no simple linear relationships between the concentrations of four heavy metals in the clam tissues and the sediments at the two sampling stations although some distinct trends were observed. Mn concentrations in the clams and sediments from the two stations showed some clear positive relationship patterns with some increments in monthly sediment concentrations resulting in increments in clam tissue concentrations. This relationship though, was not too clear-cut possibly indicating that heavy metal accumulation in clams may not be directly or solely derived from the sediments but from other sources such as living or dead suspended particles and from dissolved metals in the water.

\section{Acknowledgements}

The authors are grateful to the International Foundation for Science (IFS) for providing financial support (A/4421-1) to conduct this research work and the Department of Fisheries and Watershed Management of the Kwame Nkrumah University of Science and Technology, Kumasi for logistical support.

\section{REFERENCES}

[1] W. C. Renfro, "Transfer of ${ }^{65} \mathrm{Zn}$ from Sediments by Marine Polycheate Worm," Marine Biology, Vol. 21, 1983, pp. 305-316. doi:10.1007/BF00381087

[2] K. L. Spencer and C. L. MacLeod, "Distribution and Partitioning of Heavy Metals in Estuarine Sediment Cores and Implications for the Use of Sediment Quality Standards," Hydrology and Earth System Sciences, Vol. 6, No. 6, 2002, pp. 989-998.

[3] S. N. Luoma, "Can We Determine the Biological Availability of Sediment-Bound Trace Metals," Hydrobiologia, Vol. 176-177, 1989, pp. 379-396. doi:10.1007/BF00026572

[4] C. A. Davies, K. Tomlinson and T. Stephenson, "Heavy Metals in River Tees Estuary Sediments," Environmental Technology, Vol. 12, 1991, pp. 961-972. doi:10.1080/09593339109385095

[5] J. S. Chang, K. C. Yu, L. J. Tsai and S. T. Ho, "Spatial Distribution of Heavy Metals in Bottom Sediment of Yenshui River, Taiwan," Water Science and Technology,
Vol. 38, No. 11, 1998, pp. 159-167. doi:10.1016/S0273-1223(98)00651-9

[6] A. J. Gunther, J. A. Davis, D. D. Hardin, J. Gold, D. Bell, J. R. Cricks, G. Scelfo and M. Stephenson, "Long-Term Bioaccumulation Monitoring with Transplanted Bivalves in the San Francisco Estuary," Marine Pollution Bulletin, Vol. 38, No. 3, 1999, pp. 170-180. doi:10.1016/S0025-326X(98)00185-4

[7] C. Nasci, L. Da Ros, G. Campesan, E. S. Van Vleet, M. Salizzato, L. Sperni and B. Pavoi, "Clam Transplantation and Stress-Related Biomarkers as Useful Tools for Assessing Water Quality in Coastal Environments," Marine Pollution Bulletin, Vol. 39, No. 1, 1999, pp. 255-260. doi:10.1016/S0025-326X(99)00094-6

[8] F. Olivier, M. Ridd and D. Klumpp, "The Use of Transplanted Cultured Tropical Oysters (Saccostrea Commercialis) to Monitor Cd Levels in North Queensland Coastal Waters (Australia)," Marine Pollution Bulletin, Vol. 44, No. 10, 2002, pp. 1051-1062. doi:10.1016/S0025-326X(02)00157-1

[9] L. A. Cruz-Rodriguez and F.-L. E. Chu, "HSP70 Levels in Oyster Crassostrea Virginica Exposed to Cadmium Sorbed to Algal Food and Suspended Clay Particles," In: A. Villalba, B. Reguera, J.L. Romalde and R. Beiras, Eds., Molluscan Shellfish Safety, Consellería de Pesca e Asuntos Marítimos da Xunta de Galicia and Intergovernmental Oceanographic Commission of UNESCO, Santiago de Compostela, Spain, ISBN: 84-453-3638-X, 2003, pp. 555-567.

[10] B. S. Moses, "Growth, Biomass, Mortality, Production and Potential Yield of the West African Clam, Egeria Radiata(Lamack) (Lamellibranchia, Donacidae) in the Cross River System, Nigeria," Hydrobiologia, Vol. 196, 1990, pp. 1-15. doi:10.1007/BF00008888

[11] K. A. Obirikorang, D. Adjei-Boateng and S. Amisah, "Consumption of the Clam, Galatea Paradoxa (Born 1778) in Ghana: Human Health Implications with Reference to Heavy Metals," Water Qual Expo Health Springer Science + Business Media B.V. 1, 2009, pp. 191-201.

[12] M. K. Amador, "A Review of the Volta Clam, Egeria radiata Fishery in the Lower Volta," BSc. Thesis, Department of Fisheries and Watershed Mgt, KNUST, Kumasi, Ghana, 1997.

[13] United States Environmental Protection Agency (USEPA), Sediment Sampling, SOP\#: 2016, 1994.

[14] D. J. H. Phillips and W. W. S. Yim, "A Comparative Evaluation of Oysters, Mussels and Sediments as Indicators of Trace Metals in Hong Kong Waters," Marine Ecology-Progress Series, Vol. 6, 1981, pp. 285-293. doi: $10.3354 / \mathrm{meps} 006285$

[15] S. T. Chiu, F. S. Lam, W. L. Tze, C. W. Chau and D. Y. Ye,"Trace Metals in Mussel from Mariculture Zones, Hong Kong," Chemosphere, Vol. 41, No. 1-2, 2000, pp. 101-108. doi:10.1016/S0045-6535(99)00395-1

[16] United Kingdom Environmental Agency, "Using science 
to Create a Better Place-Environmental Quality Standards for Trace Metals in the Aquatic Environment," Science Report-SC030194, 2008.

[17] Q. Jin, F. Liang, H. Zhang, L. Zhao, Y. Huan and D. Song, "Application of Microwave Techniques in Analytical Chemistry," TrAC Trends in Analytical Chemistry, Vol. 18, No. 7, 1999, pp. 479-484. doi:10.1016/S0165-9936(99)00110-7

[18] F. A. Otchere, "Heavy Metals Concentrations and Burden in the Bivalves (Anadara (Senilia) Senilis, Crassostrea tulipa and Perna Perna) from Lagoons in Ghana: Model to Describe Mechanism of Accumulation/Excretion," African Journal of Biotechnology, Vol. 2, No. 9, 2003, pp. 280-287.

[19] G. Roesijiadi and W. E. Robinson, "Metal Regulation in Aquatic Animals: Mechanism of Uptake, Accumulation and Release," In: D. C. Malins and G. G. Ostrander, Eds., Aquatic Toxicology (Molecular, Biochemical and Cellular Perspectives), Lewis Publishers, London, 1994, pp 539.

[20] W. Huanxin, Z. Lejun and B. J. Presley, "Bioaccumulation of Heavy Metals in Oyster (Crassostrea virginica) Tissue and Shell," Environmental Geology, Vol. 39, No. 11, 1999, pp. 1216-1226.

[21] D. Connell, P. Lam, B. Richardson and R. Wu, "Introduction to Ecotoxicology," Blackwell Science Ltd, UK, 1999, p. 71.

[22] J. C. Amiard, C. Amiard-Triquet, B. Berthet and C. Metayer, "Comparative Study of the Patterns of Bioaccumulation of Essential $(\mathrm{Cu}, \mathrm{Zn})$ and Non-Essential $(\mathrm{Cd}$, $\mathrm{Pb})$ Trace Metals in Various Estuarine and Coastal Organisms," Journal of Experimental Marine Biology and Ecology, Vol. 106, 1987, pp. 73-89. doi:10.1016/0022-0981(87)90148-1

[23] C. Durou, C. Mouneyrac, C. Amiard-Triquet, "Tolerance to Metals and Assessment of Energy Reserves in the Polychaete Nereis Diversicolor in Clean and Contaminated Estuaries" Environmental Toxicology, Vol. 20, No. 1, 2005, pp. 23-31. doi:10.1002/tox.20074

[24] I. Cardoso, J. P. Granadeiro and H. Cabral "Benthic Prey Quality in the Main Mudflat Feeding Areas of Tagus Estuary: Implications for Bird and Fish Populations," Cien- cias Marinas, aňo, Vol. 34, No. 3, 2008, pp. 283-296.

[25] D. Cossa "A Review of the Use of Mytilus spp. as Quantitative Indicators of Cadmium and Mercury Contamination in Coastal Waters," Oceanologica Acta, Vol. 12, No. 4, 1989, pp. 417-432.

[26] C. R. Joiris, M. I. Azokwu, F. A. Otchere and I. B. Ali, "Mercury in the Bivalve Anadara (Senilia) Senilis from Ghana and Nigeria," Science of the Total Environment, Vol. 224, No. 1-3, 1998, pp. 181-188. doi:10.1016/S0048-9697(98)00355-6

[27] F. A. Otchere, C. Joiris, L. Holsbeek, I. B. Ali and C. J. Vanderpuye, "Heavy Metals Concentration and Burden in the Bivalves Anadara (Senilia) Senilis, Perna Perna and Crassostrea Tulipa from Ghana," In: J. Nriagu, Ed., 11th Annual International Conference on Heavy Metals in the Environment Contribution number 10161, University of Michigan, School of Public Health, Ann Arbor, MI, 2003

[28] H. L. Phelps, D. A. Wright and J. A. Mihursky, "Factors Affecting Trace Metal Accumulation by Estuarine Oysters, Crassostrea Virginica," Marine Ecology-Progress Series, Vol. 22, 2003, pp. 197-204.

[29] G. A. Ferreira, A. L. S. Machado and I. R. Zalmon, "Temporal and Spatial Variation on Heavy Metal Concentrations in the Bivalve Perna Perna (LINNAEUS, 1758) on the Northern Coast of Rio de Janeiro State, Brazil." Brazilian Archives of Biology and Technology, Vol. 47, No. 2, 2004 pp. 319-327. doi:10.1590/S1516-89132004000200020

[30] D. J. H. Phillips, "The Common Mussel, Mytilus Edulis as an Indicator of Pollution by Zinc, Cadmium, Lead and Copper. Effects of Environmental Variables on Uptake of Metals," Marine Biology, Vol. 38, No. 1, 1976, pp. 59-69. doi:10.1007/BF00391486

[31] S. N. Luoma and G. W. Bryan, "A Statistical Study of Environmental Factors Controlling Concentrations of Heavy Metals in the Burrowing Bivalve Scrobicularia Plana and the Polycheate Nereis Diversicolor," Estuarine, Coastal and Shelf Science, Vol. 15, 1983, pp. 95-108. doi:10.1016/0272-7714(82)90040-3

[32] S. N. Luoma and P. S. Rainbow, "Metals Contamination in Aquatic Environments: Science and Lateral Management," Cambridge University Press, Cambridge, 2008 